\title{
REMEMBERING THE NAME OF THE STUDENTS': A MOTIVATIONAL FACTOR FOR ELT LEARNERS AT DHAKA UNIVERSITY.
}

\author{
Kashfia Reza Tonni \\ Lecturer in English, Bangladesh University, Dhaka, Bangladesh \\ kashfia.reza@gmail.com
}

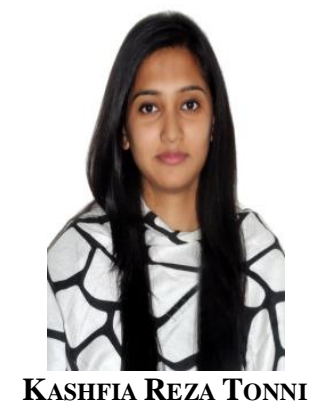

Keywords: English Class Room, Student Centered, motivational factor for ELT learners at Dhaka University, positive and negative impact on results.

\begin{abstract}
A B S T R A C T
ELT classroom has seen a gradual shift from teacher centered to student centered one and motivation of the students plays a crucial part in the classroom. Teachers have a vital role to make students motivate in the classroom. This paper reports on a study conducted, whether and to what extent remembering the name of the students' functions as a motivational factor for ELT learners at Dhaka University. Its central receptacle was on measuring the degree of motivation in the light of five key areas: positive impact on classroom behavior, positive impact on result, negative impact on classroom behavior, negative impact on results, and others. Both quantitative and qualitative data were collected from the graduate students of the English department through questionnaire and focused group interview. The analysis revealed that remembering the name of the students contained a substantial motivational factor for the students. However, it lagged behind in some areas. The study also discussed the implications of the findings and offered recommendations and limitation.
\end{abstract}

Citation: Kashfia Reza Tonni (2018). Remembering The Name Of The Students': A Motivational Factor For Elt Learners At Dhaka University. International Journal of Advanced Multidisciplinary Scientific Research (IJAMSR ) ISSN:2581-4281 Vol 1, Issue 3, May, 2018, \#Art.135, pp56-69

\section{Introduction}

Motivation has been called the "neglected heart" of language teaching (Keller, 1983). Beginning of the early 1960s, the issue of motivation has been widely explored. Teachers from every part of the world are familiar with the experience of coping with motivational problems. Although English is taught as a compulsory subject from the primary level, students consistently demonstrate low levels of proficiency in English when they reach the university level and this is so even for students who enter the department of English (Siddique and Sarwar, 2007). Moreover, In spite of being graduated the students of the department of English at the University of Dhaka become demotivated in the classroom. So, to cultivate students' motivation is very significant. Teachers have lots of accountabilities to initiate learners' motivation and keep it thriving throughout the learning process. As Pine and Boy (1997) express "pupils feel the personal, emotional structure of the teacher long before the impact of the intellectual content offered by that teacher." It is evident that teachers' performances in class will give a provocation for their students. There are a range of motivational strategies which teachers can use inside and outside the classroom and remembering their name of the students is one of them. The importance of remembering the students' name is primarily introduced 


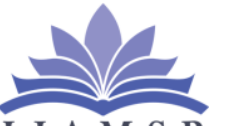

I J A M S R

\section{International Journal of}

Advanced Multidisciplinary Scientific Research (IJAMSR) ISSN:2581-4281

by Doryei (2001). As Bangladesh is a developing country, it is not all time possible to apply all the motivational strategies in the classroom. However, this strategy is not impossible to apply to promote students' motivation. This study addresses how through applying this simple strategy teachers can posit students' motivation. The findings of the study will give us deeper insight about the significance role of remembering the name of the students to cultivate ELT learners' motivation. Both teachers and students will be benefited by the findings of the study as well as it has a great implication on designing the motivational strategies for ELT learners. Moreover, this will provide valuable information for teachers about their students so that they can take necessary steps to promote their students' motivation.

\section{Literature Review}

This paper in this section highlights a number of key and often interlinked themes like the definition of motivation, different types of motivation, different types of motivational strategies, the importance of motivation in the L2 classroom, teachers' role to cultivate students' motivation, the role of remembering the name of the students on motivation.

\section{Motivation}

Motivation is one of the most important individual learner differences. It is quite difficult to define motivation in one single sentence. The success of any action usually depends on the extent to which individuals endeavor to accomplish their purpose, along with their desire to do so. According to Gilakjani, Leong and Sabouri (2012) "[motivation refers to] something that promotes, incites and stimulates action. According to R. C. Gardner (1985) motivation is a combination of effort plus desire to achieve a goal plus favorable attitudes towards the goal to be accomplished. According to Z. Dornyei (2003) "motivation is an internal attribute that is result of an external force." He (2001) also described this explicitly when he wrote the following: The motivated individual expends effort, is persistent and attentive to the task at hand, has goals, desires and aspirations, enjoys the activity, experiences reinforcement from success and disappointment from failure, makes attribution concerning success or failure, is aroused, and makes use of strategies to aid in achieving goals. So motivation is an abstract idea which leads individuals to attain their success concerning any particular issues. In general, motivation is dynamic in nature and can vary from moment to moment depending on the learning context or task.

\section{Different Types of Motivation}

There are different types of motivations identified by different theorists, such as, Brown (1981) identifies three types of motivations: (1) global motivation, which consists of a general orientation to the goal of learning an L2. (2) Situational motivation, which varies according to the situations in which learning takes place. (3) Task motivation which is the motivation of performing particular learning tasks. Moreover, Gardner and Lambert (1985) differentiate between two types of motivations. One is integrative motivation, which is an interest in interacting with the L2 language group. Another one is instrumental motivation, which refers to an interest in the more materialistic and practical advantages of learning a new language. The other types of motivations are- Extrinsic Motivation and intrinsic motivation. "Extrinsic motivation is the motivation that achieve some instrumental end, such as earning a reward or avoiding a punishment." (Dornyei, 1998) and "Intrinsic motivation refers to the motivation to engage learners in an activity because that activity is enjoyable and satisfying to do." (Dornyei, 1998)

\section{The Role of Motivation in Language Learning}

The issue of motivation is so important that other consideration about teaching methodology seem to pale in comparison. According to M. Rost (2006) motivation is the essence of language teaching. Bahous, Bacha, Nabhani (2011) in their research paper also shows the significance of motivation in language classroom.

\section{Different Strategies to Cultivate Motivation}

There are various types of strategies which are used to cultivate motivation in the language classroom.. Such as

1. Creating the basic motivational conditions, which involve setting the scene for the use of motivational strategies;

2. Generating students' motivation, which roughly corresponds to the preactional phase in the model;

3. Maintaining and protecting motivation, which parallels to the actional segment;

4. Encouraging positive self-evaluation, which corresponds to the postactional phase; Dornyei and Otto (1998) 


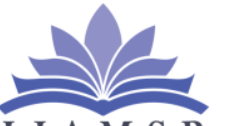

I J A M S R

\section{International Journal of}

Advanced Multidisciplinary Scientific Research (IJAMSR) ISSN:2581-4281

There are also some other strategies like clarity of purpose (Burden, 2004), positive learning experience (Clement, 1980), cooperative group teaching (Ghaith, 2003), reordering curriculum to cater for students' differences and help them make sense of what they encounter in their courses which will maximize learning (Fortini \& Fizpatrick, 2000).

\section{Teachers' Role to Cultivate Students' Motivation}

Teachers play a vital role to cultivate students' motivation. According to Dornyei (2001) teachers' behavior is a powerful "motivational tool". For Alison (1993), a key element to motivate students is to establish a relationship of mutual trust and respect with the learner. Good teacher-students relationship is an imperative factor in motivation. Teachers' behavior can influence the students' engagement in the class. (Kaboody, 2003)

\section{The Role of Remembering the Name of the Students'}

Remembering the name of the students has a great impact on motivation. It makes them feel that the teachers pay attention to them, which is recognized by Dornyei as an important motivational factor (Dornyei, 2001). He also adds students need to feel that teachers pay personal attention to them. They should also make them feel that they "care for the students' learning." In his book he categorizes this as "Take the students" learning very seriously." Moreover, Dornyei describes that although it is very tough to pay attention to all the students in a class it is not impossible to follow some simple strategies to do this and he demonstrates twelve strategies where "remembering the students' name" is proclaimed as the first most important point in the strategy list. In addition, Rogers (1969) identified that the significant learning can be facilitated by establishing an interpersonal relationship between the teachers and the learners. Similarly, Dornyei (1994) describes a framework of L2 motivation outlines where three key components of the teachers' role explain that impact on L2 motivation. The first key component is the affective motive where the students' desire to please the teachers and it is obtained through making an interpersonal relationship with the students.

\section{Methodology}

The purpose of this study is to investigate whether and to what extent remembering the name of the students by their teachers helps to motivate ELT learners at Dhaka University. This is an exploratory study in which questionnaire was used as quantitative data collection tool because it is an instinctive way to collect data within a short time. Besides, a focus group interview was used as a tool to collect more exhaustive and inclusive qualitative data regarding this issue.

\section{Sampling}

Convenience sampling method was used to select the subject of this study. The subjects were 36 graduates at the department of English of Dhaka University.

\section{Instruments and Administration of the Study}

A questionnaire and a focus group interview were used as data collection tools. The questionnaire contains twenty items which are divided into two groups according to positive impact and negative impact. In addition, the two groups were divided into five sub categories, for instance, positive impact on classroom behavior, positive impact on result, the negative impact of classroom behavior, negative impact on result and others.

The items were designed to bring out responses following five-point Likert Scale ranging from strongly agrees to strongly disagree. The questionnaire was administered by the researcher himself. Moreover, the questionnaire was distributed by the researcher himself and the purpose of the study was explained by the researcher before distributing the questionnaire. The participants filled in the questionnaire in front of the researcher and returned them to her after completion.

Furthermore, focus group interview was used to collect qualitative data where the researcher conducted the interview with six graduate students of English and recorded their responses. The instrument was used because its consequences a deep insightful discussion. To sum up, before collecting data from the focus group the research8er outlined the objective and the purpose of the study as well as what sort of issues will be discussed in the interview. 
https://doi.org/10.31426/ijamsr.2018.1.3.135

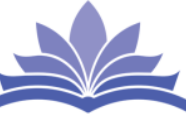

I J A M S R

\section{International Journal of} Advanced Multidisciplinary Scientific Research (IJAMSR) ISSN:2581-4281

\section{Data Processing and Analysis}

In this study questionnaire produced quantitative data while the focus group interview produced qualitative data. The quantitative data was analyzed through using Microsoft Office Excel (version 2010). To analyze each variable descriptive statistics (frequencies, mean, grand, mean) are used. Data collected through focus group interview were categorized through a process of qualitative thematic analysis. The researcher at first read the data carefully; then transcribing the data; then identifying key issues with them and organizing these issues into a set of broader categories. Mixed method was used to collect and analyze the data. It becomes helpful for the researcher to substantiate particular conclusions from two perspectives. It is also helpful to obtain more meaningful understanding and deeper insight on the phenomenon.

\section{Results and Discussion of the Findings}

Research Question: To what extent remembering the name of the students is a motivational factor for ELT learners at Dhaka University?

\section{Results of the Data Collected through Questionnaire}

\section{Positive Impact}

\section{Positive Impact on Classroom Behavior}

The results of this particular impact are presented in Table 1 below.

Table 1: Questionnaire Results: positive impact on classroom behavior

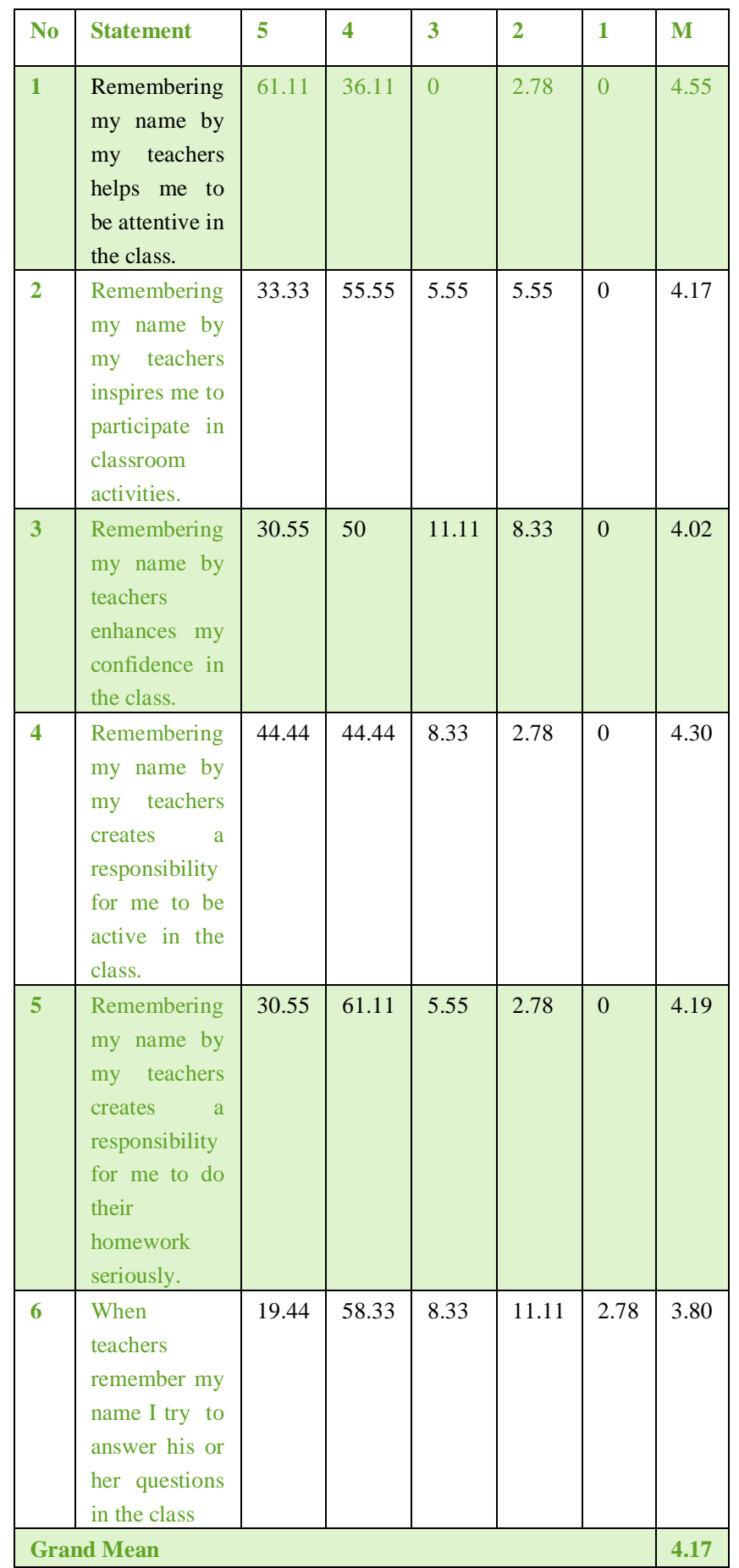

5= Strongly Agree 4= Agree 3= Undecided $2=$ Disagree $1=$ Strongly Disagree $\mathrm{M}=$ mean 


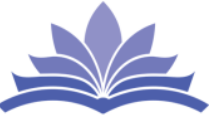

I J A M S R

\section{International Journal of Advanced Multidisciplinary Scientific Research (IJAMSR) ISSN:2581-4281}

The result in the Table 1 delineates that the majority of the respondents $(97.22 \%)$ have asserted that when teachers remember their name they become more attentive in the classroom. In the same way $80.55 \%$ of the respondents have admitted that it also inspires them to participate in the classroom activities. Moreover, $88.88 \%$ of the participants have agreed that it enhances their confidence level in the classroom, which is an important motivational strategy acknowledged by Thanasoulas (2002). In addition, $80.55 \%$ and $91.66 \%$ of the respondents possess that it creates a responsibility for them to be active in the class as well as do their (teachers') homework seriously. Similarly, $77.77 \%$ of the participants think that it makes them interested to answer the questions which are risen by the teachers in the class.

So the findings in Table 1 indicate that a vast majority of the participants have consented that remembering their name by their teachers has a positive impact on classroom behavior. It makes them more responsible as well as motivated in the class. Moreover, they feel themselves as a responsible person.

\section{Positive Impact on Results}

The findings of this question are represented in Table 2 below.

Table 2: Questionnaire Results: Positive impact on result

\begin{tabular}{|l|l|l|l|l|l|l|l|}
\hline No & Statement & $\mathbf{5}$ & $\mathbf{4}$ & $\mathbf{3}$ & $\mathbf{2}$ & $\mathbf{1}$ & $\mathbf{M}$ \\
\hline 7 & $\begin{array}{l}\text { When teacher } \\
\text { remembers my } \\
\text { name it } \\
\text { becomes a } \\
\text { responsibility } \\
\text { for me to } \\
\text { obtain a good } \\
\text { score in his or } \\
\text { her course. }\end{array}$ & $\begin{array}{l}\text { I think when } \\
\text { teacher } \\
\text { remembers my } \\
\text { name he or she } \\
\text { expects good } \\
\text { results from } \\
\text { me. }\end{array}$
\end{tabular}

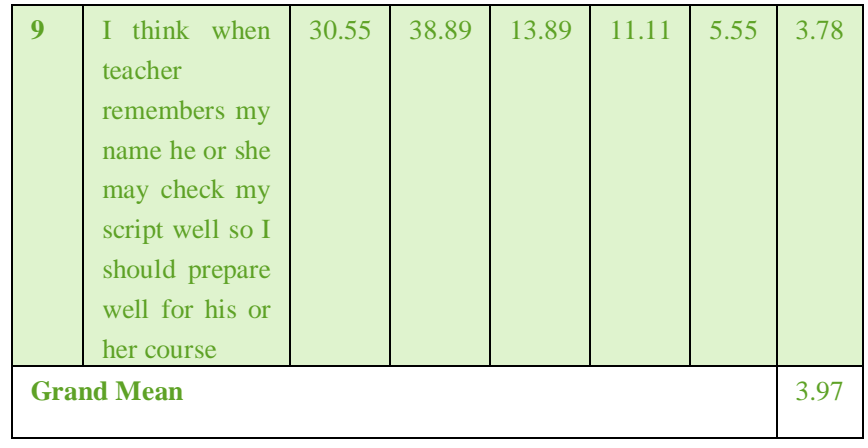

5= Strongly Agree 4= Agree 3= Undecided 2= Disagree $1=$ Strongly Disagree $\mathrm{M}=$ mean

The findings of the Table 2 demonstrate that $66.66 \%$ of the respondents think that when their teachers remember their name it generates a responsibility for them to obtain good score in their course. Similarly, $61.11 \%$ of the participants agree that when teachers remember their name they expect good results from them so they prepare well. Furthermore, another important finding is that $69.44 \%$ of the participants concur that it makes them liable to prepare well for the exam of their course as when the teachers remember their name they (teachers) may check their scripts as well. From the results of the Table 2 we can understand that remembering the name of the students has a positive impact not only on classroom behavior but also on results.

\section{Negative impact}

\section{Negative Impact on Classroom Behavior}

The findings of the negative impact on classroom behavior are represented in Table 3

Table 3: Questionnaire Results: Negative impact on classroom behavior 
https://doi.org/10.31426/ijamsr.2018.1.3.135

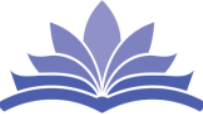

I J A M S R

\section{International Journal of}

Advanced Multidisciplinary Scientific Research (IJAMSR) ISSN:2581-4281

\begin{tabular}{|c|c|c|c|c|c|c|c|}
\hline No & Statement & 5 & 4 & 3 & 2 & 1 & M \\
\hline 10 & $\begin{array}{l}\text { The teachers } \\
\text { who } \\
\text { remember my } \\
\text { name I try to } \\
\text { be absent } \\
\text { from his or } \\
\text { her class } \\
\text { when I cannot } \\
\text { complete the } \\
\text { prescribed } \\
\text { homework. }\end{array}$ & 0 & 41.67 & 2.78 & 44.44 & $\begin{array}{l}11 . \\
11\end{array}$ & $\begin{array}{l}2.7 \\
5\end{array}$ \\
\hline 11 & $\begin{array}{l}\text { When } \\
\text { teachers } \\
\text { remember my } \\
\text { name I try to } \\
\text { preserve from } \\
\text { the sight of } \\
\text { them by } \\
\text { staying at the } \\
\text { back bench if } \\
\text { I do not do } \\
\text { the prescribed } \\
\text { homework. }\end{array}$ & $\begin{array}{l}5 . \\
55\end{array}$ & 33.33 & 8.33 & 50 & $\begin{array}{l}2.7 \\
8\end{array}$ & $\begin{array}{l}2.8 \\
9\end{array}$ \\
\hline 12 & $\begin{array}{l}\text { I think" } \\
\text { remembering } \\
\text { the name of } \\
\text { the students } \\
\text { create } \\
\text { discrimination } \\
\text { in the class." }\end{array}$ & $\begin{array}{l}2 . \\
78\end{array}$ & 22.22 & 27.78 & 36.11 & $\begin{array}{l}11 . \\
11\end{array}$ & $\begin{array}{l}2.6 \\
9\end{array}$ \\
\hline 13 & $\begin{array}{l}\text { When } \\
\text { teachers } \\
\text { remember my } \\
\text { name I try to } \\
\text { copy from my } \\
\text { classmates in } \\
\text { his or her } \\
\text { class if I do } \\
\text { not complete } \\
\text { the prescribed } \\
\text { lesson. }\end{array}$ & 0 & 47.22 & 13.89 & 33.33 & $\begin{array}{l}5.5 \\
5\end{array}$ & $\begin{array}{l}3.0 \\
9\end{array}$ \\
\hline \multicolumn{7}{|c|}{ Grand Mean } & $\begin{array}{l}2.8 \\
5\end{array}$ \\
\hline
\end{tabular}

5= Strongly Agree 4= Agree 3= Undecided 2=

Disagree $1=$ Strongly Disagree $\mathrm{M}=$ mean
The findings of the Table 3 show that $41.67 \%$ of the respondents think that the teachers who remember their name, they try to be absent from their class when they cannot complete the prescribed homework. However, $55.55 \%$ of the participants disagree with this question. This result depicts that it has a slight negative impact regarding this issue. In addition, only $38.85 \%$ of the respondents think that it (when teachers remember their name) makes them bound to stay on the back bench if they become unable to do the prescribed homework. Similarly, $25 \%$ of the respondents demonstrate that remembering the name of the students creates discrimination in the class. The other important result is that $47.22 \%$ of the participants delineate that when teachers remember their name they try to copy from their classmates if they become unable to complete the prescribed lesson. So the results of the Table 3 represent that although remembering the name of the students has a few negative impacts on classroom behavior regarding some issues it does not have any great negative impact on classroom behavior

\section{Negative Impact on Results}

The findings of the negative impact on results are demonstrated in Table 4

Table 4: Questionnaire Results: Negative impact on results 
https://doi.org/10.31426/ijamsr.2018.1.3.135

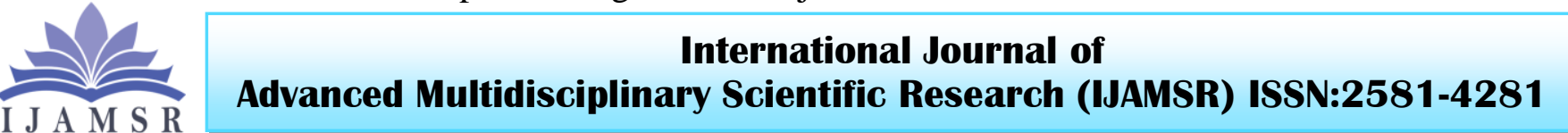

\begin{tabular}{|c|c|c|c|c|c|c|c|}
\hline $\mathbf{N}$ & Statement & 5 & 4 & 3 & 2 & 1 & M \\
\hline (1) & $\begin{array}{l}\text { When } \\
\text { teacher } \\
\text { remembers } \\
\text { my name I } \\
\text { try to } \\
\text { concentrat } \\
\text { e only his } \\
\text { or her } \\
\text { course. }\end{array}$ & 0 & $\begin{array}{l}13.8 \\
9\end{array}$ & $\begin{array}{l}13.8 \\
9\end{array}$ & $\begin{array}{l}61.1 \\
1\end{array}$ & $\begin{array}{l}11.1 \\
1\end{array}$ & $\begin{array}{l}2.3 \\
0\end{array}$ \\
\hline 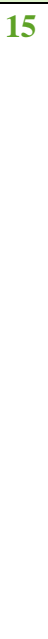 & $\begin{array}{l}\text { I think" } \\
\text { Sometimes } \\
\text { teachers } \\
\text { remember } \\
\text { some } \\
\text { students } \\
\text { name as an } \\
\text { immoral } \\
\text { person by } \\
\text { any } \\
\text { misconduc } \\
\text { t and they } \\
\text { try to give } \\
\text { poor marks } \\
\text { to them in } \\
\text { the exam." }\end{array}$ & 0 & $\begin{array}{l}22.2 \\
2\end{array}$ & $\begin{array}{l}33.3 \\
3\end{array}$ & $\begin{array}{l}36.1 \\
1\end{array}$ & 8.33 & $\begin{array}{l}2.6 \\
9\end{array}$ \\
\hline \multicolumn{7}{|c|}{ Grand Mean } & $\begin{array}{l}2.4 \\
9\end{array}$ \\
\hline
\end{tabular}

Others

The findings about other issues are presented in Table 5 Table 5: Questionnaire Results: Others negative impact

5= Strongly Agree 4= Agree 3= Undecided 2= Disagree $1=$ Strongly Disagree $\mathrm{M}=$ mean

The findings of the Table 4 illustrate that only $13.89 \%$ of the participants demonstrate that when teachers remember their name they only concentrate on their courses while $72.22 \%$ of the respondents totally disagree with this question. Here we can see a huge gap between the views of the participants regarding this issue. In the same way, only $22.22 \%$ of the respondent's consent that if their teachers remember they're as an immoral person with any kind of misconduct, they will try to give them poor marks on the exam. To sum up, the findings of the Table 4 describes that remembering the name of the students does not have any negative impact regarding students' results. 
https://doi.org/10.31426/ijamsr.2018.1.3.135

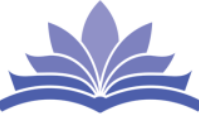

I J A M S R

\section{International Journal of} Advanced Multidisciplinary Scientific Research (IJAMSR) ISSN:2581-4281

\begin{tabular}{|c|c|c|c|c|c|c|c|}
\hline $\begin{array}{l}\mathbf{N} \\
\mathbf{0}\end{array}$ & $\begin{array}{l}\text { Statemen } \\
\mathrm{t}\end{array}$ & 5 & 4 & 3 & 2 & 1 & M \\
\hline 16 & $\begin{array}{l}\text { When } \\
\text { teachers } \\
\text { remember } \\
\text { my name } \\
\text { I do not } \\
\text { feel } \\
\text { happy. }\end{array}$ & $\begin{array}{l}2.7 \\
8\end{array}$ & 0 & $\begin{array}{l}11.1 \\
1\end{array}$ & $\begin{array}{l}44.4 \\
4\end{array}$ & $\begin{array}{l}41.6 \\
7\end{array}$ & $\begin{array}{l}1.7 \\
8\end{array}$ \\
\hline 17 & $\begin{array}{l}\text { When } \\
\text { teachers } \\
\text { remember } \\
\text { my name } \\
\text { I feel } \\
\text { very shy. }\end{array}$ & 0 & 2.78 & 2.78 & $\begin{array}{l}58.3 \\
3\end{array}$ & $\begin{array}{l}36.1 \\
1\end{array}$ & $\begin{array}{l}1.7 \\
2\end{array}$ \\
\hline 18 & $\begin{array}{l}\text { When } \\
\text { teachers } \\
\text { remember } \\
\text { my name } \\
\text { he or she } \\
\text { sometime } \\
\text { s } \\
\text { overreact } \\
\text { s on my } \\
\text { mistakes. }\end{array}$ & $\begin{array}{l}2.7 \\
8\end{array}$ & $\begin{array}{l}22.2 \\
2\end{array}$ & $\begin{array}{l}22.2 \\
2\end{array}$ & $\begin{array}{l}41.6 \\
7\end{array}$ & $\begin{array}{l}11.1 \\
1\end{array}$ & $\begin{array}{l}2.6 \\
4\end{array}$ \\
\hline 19 & $\begin{array}{l}\text { I think } \\
\text { when } \\
\text { teachers } \\
\text { remember } \\
\text { my name } \\
\text { he or she } \\
\text { will give } \\
\text { me more } \\
\text { marks } \\
\text { than other } \\
\text { students. }\end{array}$ & 0 & $\begin{array}{l}38.8 \\
9\end{array}$ & 8.33 & $\begin{array}{l}44.4 \\
4\end{array}$ & 8.33 & $\begin{array}{l}2.7 \\
8\end{array}$ \\
\hline 20 & $\begin{array}{l}\text { When } \\
\text { teachers } \\
\text { remember } \\
\text { my name } \\
\text { it } \\
\text { becomes } \\
\text { a pressure } \\
\text { for me. }\end{array}$ & 0 & 5.55 & $\begin{array}{l}13.8 \\
9\end{array}$ & 50 & $\begin{array}{l}30.5 \\
5\end{array}$ & $\begin{array}{l}1.9 \\
4\end{array}$ \\
\hline \multicolumn{7}{|c|}{ Grand Mean } & $\begin{array}{l}2.1 \\
7\end{array}$ \\
\hline
\end{tabular}

The results in Table 5 show that a vast majority of $(86.11 \%)$ of the respondents disagree with the question that when teachers remember their name they do not feel happy while only $2.78 \%$ of the participants agree with this. In the same way, $94.44 \%$ of the participants think it does not make them feel shy. So it does not enhance their affective factor Krashen, 1981). Moreover, barely $25 \%$ of the respondents express that when teachers remember their name they (teachers) sometimes overreact on their (student) mistakes. The most important finding is that $80.55 \%$ of the respondents demonstrate that they do not think when teacher remembers their name he or she will give them more marks on the exam than others. So it reveals that it does not create any discrimination. In addition, merely $38.89 \%$ of the respondents agree that when teachers remember their name it becomes a pressure for them. In conclusion, the findings of the Table 5 confirm that remembering the name of the students does on have any negative impact on other issues.

\section{Comparative Measurement of the Five Constructs of Positive and Negative Impact}

In measuring positive and negative impact the researchers actually measure five constructs regarding these issues. In this study, the researcher has found that in some areas, remembering the name of the students has a substantial degree of positive impact. The comparative analysis of the five constructs will give a clear picture of the positive and negative impact of remembering the name of the students on ELT learners at Dhaka University. 


\section{$14 \quad$ International Journal of I J A M S R Advanced Multidisciplinary Scientific Research (IJAMSR) ISSN:2581-4281}

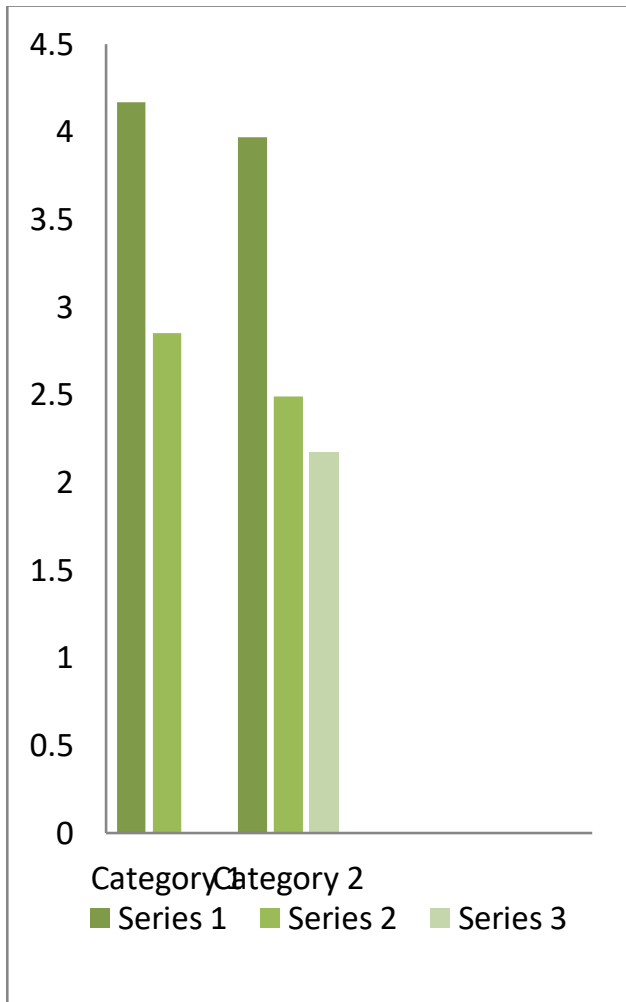

The bar chart above is divided into two categories where category (1) demonstrates the impact on classroom behavior and category (2) demonstrates the impact on results and others. Series 1 depicts the positive impact on classroom behavior (4.17) as well as positive impact on results (3.97). Series 2 describes the negative impact on classroom behavior (2.85) and negative impact on results (2.49). Similarly, series 3 depicts another negative impact (2.17). In conclusion, we can say that the bar chart clearly explains remembering the name of the students is a motivational factor for ELT learners at Dhaka University to a great extent.

\section{Results of focused group interview}

The focus group interview helps to illustrate the detail and insightful impact of remembering the name of the students' to cultivate ELT learners' motivation. The researcher conducted a focus group interview with six learners selected from the subjects of the study where they participated in a spontaneous discussion. The role of the researcher in the interview was a moderator. The researcher asked the learners various types of questions so that detailed data can be collected. The interview was recorded and read carefully by the researcher. The imperative issues are identified and organized in a categorical way.

\section{Students' perspective on remembering their name}

All of the students are aware of the research topic. They defined it as a significant issue which should be considered by all the teachers of the department. One of the students explained that to me it is a very important issue, however, most of the time our teachers do not take it seriously. Another added sometimes they even don't recognize us in the corridor, although they taught us several courses. When students were asked to what extent it is a motivational strategy for ELT learners.

One of the students' responses was like the following:

"They taught us motivational theory, but they are hardly aware of the importance of this theory. Yes... It is not all time possible to apply all the theories in classroom context, but at least they can talk to us or pretend that they care for us. They are actually unconscious about their great influence on us. Their little encouragement creates a huge responsibility for us to keep their expectation."

Students' attitude towards using their name in the class to describe anything

From this discussion, it is found that almost all of them feel very happy when they understand that their teachers know them. Two of them reply regarding this question were "we become very happy when teachers remember our name and use our name in the class as an example of describing something. We actually feel ourselves special."

Students' attitude when teachers do not remember their name

Students were asked how they feel when their teachers do not remember their name. All most all of them asserted one thing that they feel inferior to those who are well known to their teachers. One of the students' responses was like the following:

When I was in school and college, almost every teacher remembered my name, knew my name as a good student, but when I got admitted to Dhaka University the 


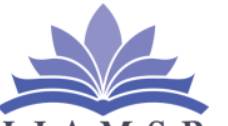

I J A M S R

\section{International Journal of}

Advanced Multidisciplinary Scientific Research (IJAMSR) ISSN:2581-4281

scenario had changed. There were lots of students in my class. Most of them were from an urban area, but I was from rural area. So I could not mingle with them easily. I was also very introvert. My result was not so good. Honestly speaking, no teachers actually recognizes me in my class. When my teachers talk to my other classmates, I feel very inferior to them. I also become very nostalgic because once upon a time I was like them.

\section{Does it have any impact on motivation?}

From the discussion of this question it was found that all of them agree that it helps them to motivate in the classroom. All of them think it creates a responsibility for them to be motivated in the class. Some of their responses were

Of course I become very attentive in the class when I realize that my teachers know me. I do not want to lose my face.

I do not want that he or she misunderstands me. So I become very active in those classes.

I like those teachers who know me. I always think how they feel if I have done any misconduct in their classes. So I always try to avoid hurting them.

It is not only a motivational strategy for the classroom, but also for results as one of them replied "I always try to write well in those courses. I think if I do not write well how will my teachers think about me? I am very careless. I really care for them."

\section{Implication of the Findings}

The findings of the study show that there is a great significance of remembering the students' name on cultivating their motivation. The results of the study suggest that it has a great influence on motivation. It will be helpful for the teachers to know the value of themselves and how they can motivate their students inside and outside the classroom through using this simple strategy.

\section{Recommendation}

This study recommends that remembering the name of the students' is an important motivational strategy for ELT learners. Teachers should pay attention regarding this issue. Moreover, further research should be conducted not only on graduate learners' but also on undergraduate learners'. Similarly, further research should be done according gender variables.

\section{Limitation of the Study}

The study has some limitations. First of all the sample size was small. It only gave us the clear picture of the perspective of graduate students of the English department of Dhaka University about this issue. Moreover, the participants were from 2014-2015 sessions. Other session' students should be used. So it is not possible to claim that it is applicable for all the graduate learners of ELT in Bangladesh because of the small sample size. Similarly, the responses can be varied according to gender. In this research the gender issue is neglected. Moreover, a questionnaire survey was done to conduct the research which has some limitation. Sometimes questionnaires produce unreliable data (Doryei, 2007) because sometimes participants answer the questions without reading carefully. It can create a change in the results. According to Moser and Kalton (1971) it usually results in superficial data. Focus group interview also has some limitations which are acknowledged by Smithson (2000), for instance, sometimes it dominates the research process as well as transcribing the interview is difficult. So, to some extent this study has some limitations.

\section{Conclusion}

In this paper the researcher addressed to what extent remembering the name of the students act as a motivational factor for ELT learners' at Dhaka University. The findings have revealed that it has a substantial degree of impact on ELT learners' motivation. The findings also have depicted, among the five areas of investigation, students become very attentive in those teachers' classes who know them or remember their name. The findings suggest that it will be wise if teachers draw attention to this fact and take it seriously as it is the easiest process to cultivate the students' motivation. Every learner is different and thus different motivational strategies may work differently with each group of students. However, it is significant that teachers should be aware of their action and behavior. Therefore, remembering the students' name does not require any logistic support or any expensive thing, but the awareness of the teachers' about this particular issue. Especially it is a very helpful motivational tool for ELT learners in developing countries like Bangladesh. 


\section{References}

1) Alison, J., \& Halliwell, S. (2002). Challenging Classes: Focus on Pupil Behavior. London, UK: CILT

2) Bacha, Bahous, Nabhani. (2011). Motivating Students in the EFL Classroom: A Case Study of Perspectives. Canadian center of Science and Education, vol. 4

3) Brown, H. (1981). Affective Factors in Second Language Learning in J. Alatis, H. Altman, and P. Alatis (eds.). The Second Language Classroom: Directions for the 1980s. Oxford University Press: New York.

4) Burden, P. (2004). An Examination of Attitude Change toward the Use of Japanese in a University English Conversations' Class. RELC, 35 (1), 21 -36.

5) Clement, R., Dornyei, Z., \& Noels, K. A. (1994). Motivation, self-confidence and group cohesion in the foreign Language Classroom. Language Learning, A journal of research in language studies, vol. 44, 417- 448

6) Dornyei, Z. (1994). Motivation and Motivating in the Foreign Language Classroom: Modern Language Journal, 78, 273-284

7) Dornyei, Z. and Otto, I. (1998). Motivation in Action : A Process Model of L2 Motivation. Working Papers in Applied Linguistics (London Themes Valley University), University of Nottingham. Vol. 4: 43- 69

8) Dornyei, Z (2001). Motivational Strategies in the Language Classroom. Cambridge University Press: Cambridge

9) Dornyei, Z. (2001). Research Method in Applied Linguistics. Oxford University Press: New York

10) Dornyei, Z (2001) New Themes and Approaches in Second Language Motivation Research, Annual review of Applied Linguistics, 21, 43-59

11) Dornyei, Z. (2003). Attitudes, Orientations, and Motivations in Language Learning: Advances in Theory Research and Application. Oxford: Blackwell

12) Fortini, M. \& Fitzpatrick, M. (2000). The universal design for promoting self- determination. In R. A. Villa\& J. S. Thousand (Eds.) Restricting for caring and effective education: piecing the puzzle together( $2^{\text {nd }}$ ed) (pp. 575-89)

13) Ghaith, Gh. (2003) The relationship between Forms of Instruction, Achievement and Perceptions of Classroom Climate Educational Research, 45 (1)
14) Kaboody, A. M. (2013). Second Language Motivation; The Role of Teachers in Learners Motivation. Journal of Academic and Applied Studies. Vol. (3)4

15) Keller, J. M. (1983). Motivational Design of Instruction. In C.M. Relgeluth (Ed.) Instructional design theories and models: An overview of their current status. Hillsdale, NJ: Erlbaum

16) Krashen, S (1981). Second Language Acquisition and Second Language Learning. Oxford: Pergamon

17) Moser, C. A. and Kalton (1971). Survey Method in Social Investigation. London: Heinemann

18) M. Rost, (2006) Generating Students Motivation. Series Editor of World View,

19) Pine , G. J and Boy, A. V. (1997). Language Centered Teaching: A Humanistic View. In Li wangyue. (2008). An Investigation into Affective Factors in English Learning. Laoning Normal University

20) R. C. Gardner,(1985).Social Psychology in Second Language Learning, Edward Arnold Limited: London, Great Britain

21) Rogers, C. R. (1969). Freedom to Learn. In Cai xi. (2008). Affective Value of Cooperative Learning in Foreign Language Learning and Teaching. Shanghai International Studies University.

22) Siddique, $R \&$ Sarwar B. (2007). 'ESP Courses in Literature: Exploring the Language Based Approach'Spectrum Vol 5, June 2007

23) Smithson, J. (2000) Using and Analyzing Focus Groups: Limitation and Possibilities. International Journal of Social Research Methodology 3/2: 103-19

24) .Thanasouls, D (2002). Motivation and Motivating in the Foreign Language Classroom. Vol. vii. www. Geocities.com/glossologos/

\section{Appendix}

Questionnaire to Assess Remembering the Name of the Students as a Motivational Factor for ELT Learners' Motivation.

Part1: Personal Profile

Please give your personal information as asked

Name:

Roll:

Session: 
https://doi.org/10.31426/ijamsr.2018.1.3.135

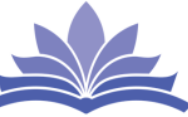

\section{International Journal of} Advanced Multidisciplinary Scientific Research (IJAMSR) ISSN:2581-4281

Part 2: Statement to assess remembering the name of the students as a motivational factor for ELT learners'

Please give your opinion about the statements below by ticking ONE answer for each.

\section{Questionnaire}

\begin{tabular}{|c|c|c|c|c|c|c|}
\hline $\begin{array}{l}\mathbf{N} \\
\mathbf{O}\end{array}$ & Statement & $\begin{array}{l}\text { Strong } \\
\text { ly } \\
\text { Agree }\end{array}$ & $\begin{array}{l}\text { Agr } \\
\text { ee }\end{array}$ & $\begin{array}{l}\text { Undecid } \\
\text { ed }\end{array}$ & $\begin{array}{l}\text { Disagr } \\
\text { ee }\end{array}$ & $\begin{array}{l}\text { Strong } \\
\text { ly } \\
\text { Disagr } \\
\text { ee }\end{array}$ \\
\hline 1 & $\begin{array}{l}\text { Remember } \\
\text { ing my } \\
\text { name by } \\
\text { my } \\
\text { teachers } \\
\text { helps me to } \\
\text { be attentive } \\
\text { in the class }\end{array}$ & & & & & \\
\hline 2 & $\begin{array}{l}\text { Remember } \\
\text { ing my } \\
\text { name by } \\
\text { my } \\
\text { teachers } \\
\text { inspires me } \\
\text { to } \\
\text { participate } \\
\text { in } \\
\text { classroom } \\
\text { activities }\end{array}$ & & & & & \\
\hline 3 & $\begin{array}{l}\text { Remember } \\
\text { ing my } \\
\text { name by } \\
\text { my } \\
\text { teachers } \\
\text { enhances } \\
\text { my } \\
\text { confidence } \\
\text { in the } \\
\text { classroom }\end{array}$ & & & & & \\
\hline 4 & $\begin{array}{l}\text { Remember } \\
\text { ing my } \\
\text { name by } \\
\text { my } \\
\text { teachers }\end{array}$ & & & & & \\
\hline
\end{tabular}

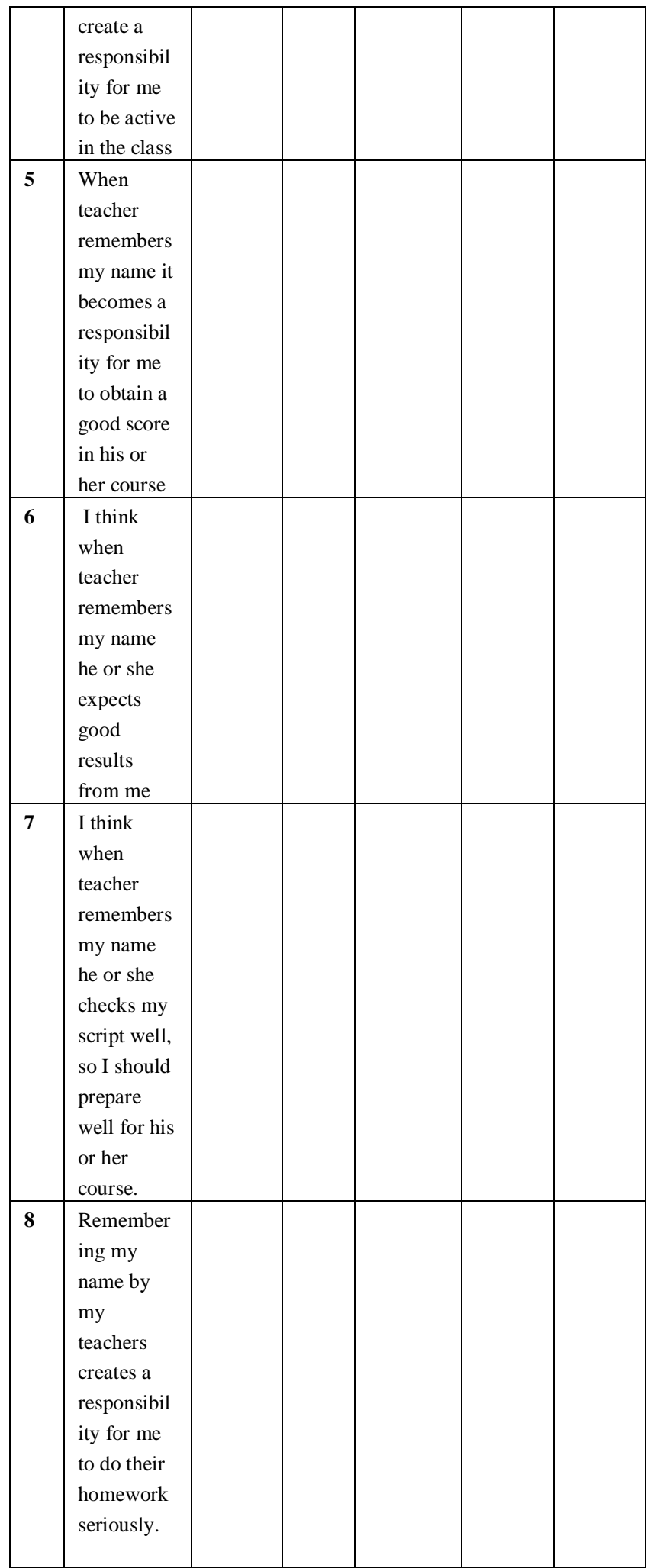


https://doi.org/10.31426/ijamsr.2018.1.3.135

International Journal of Advanced Multidisciplinary Scientific Research (IJAMSR) ISSN:2581-4281

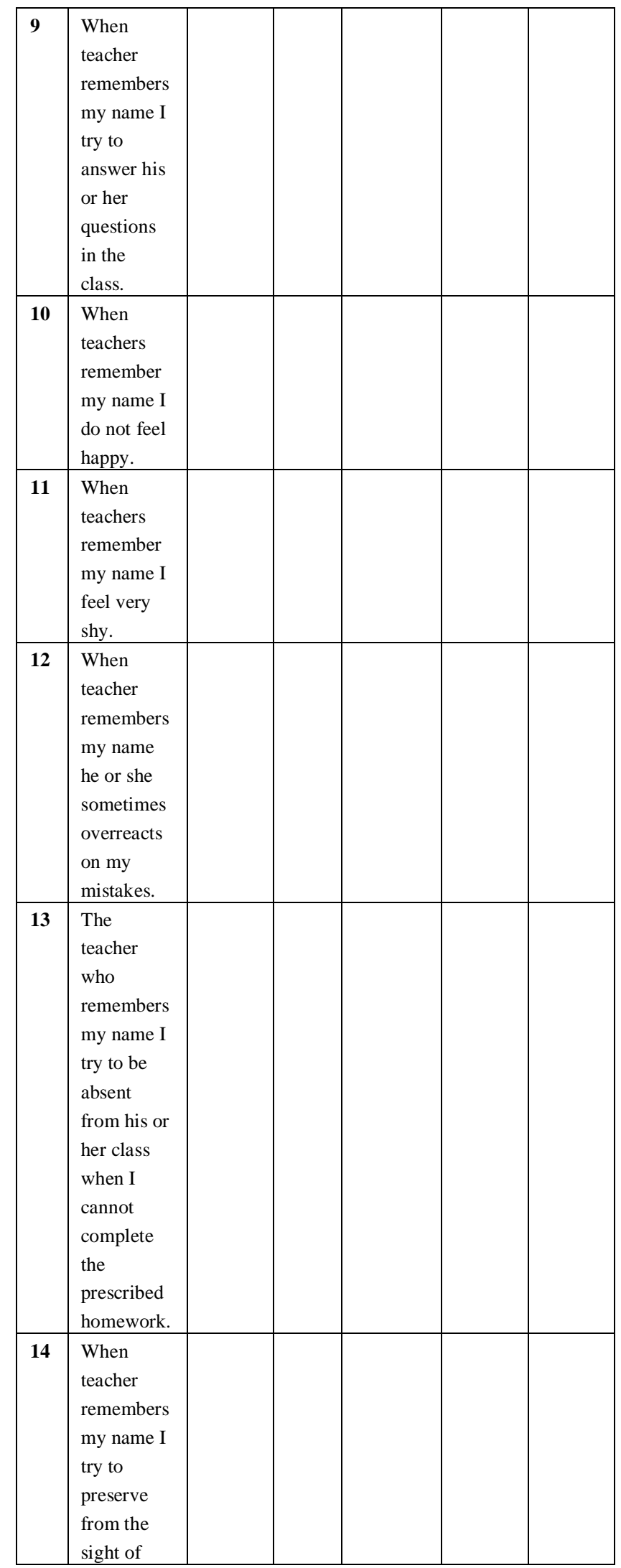

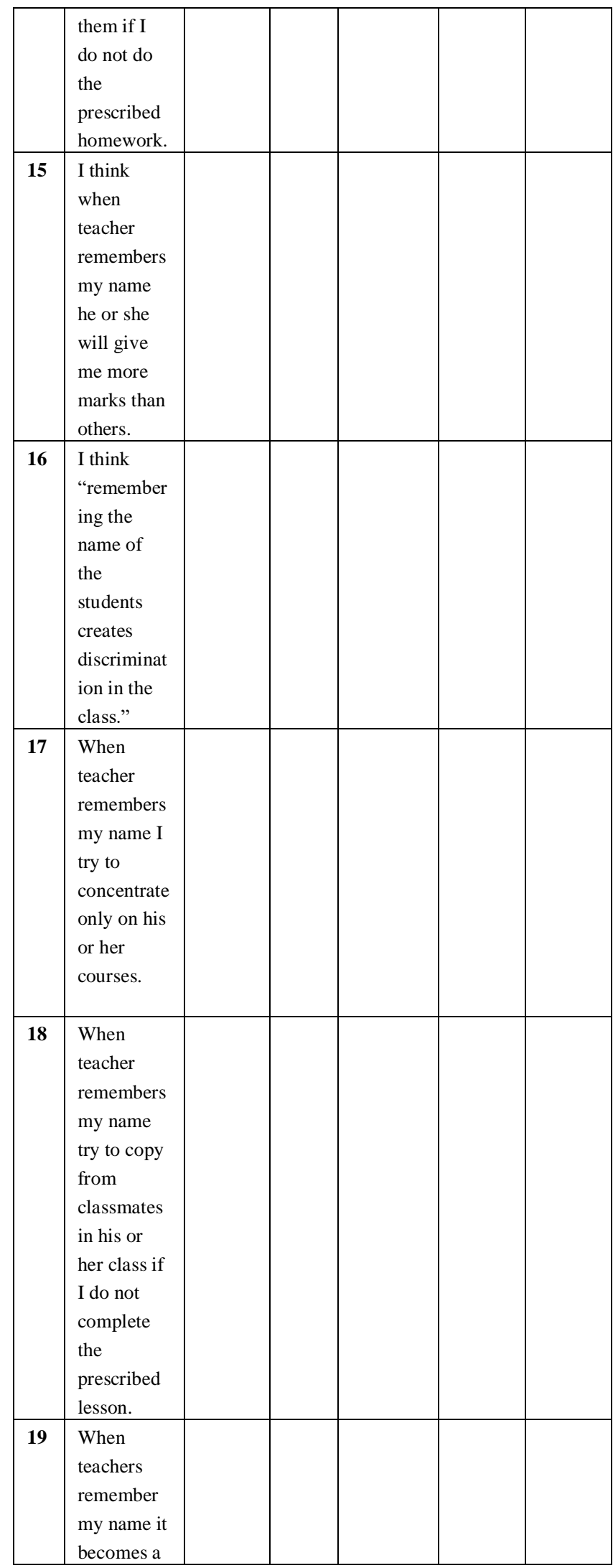


International Journal of Advanced Multidisciplinary Scientific Research(IJAMSR) ISSN:2581-4281 Volume 1, Issue 3, May,2018

https://doi.org/10.31426/ijamsr.2018.1.3.135

International Journal of
I J A M S R Advanced Multidisciplinary Scientific Research (IJAMSR) ISSN:2581-4281

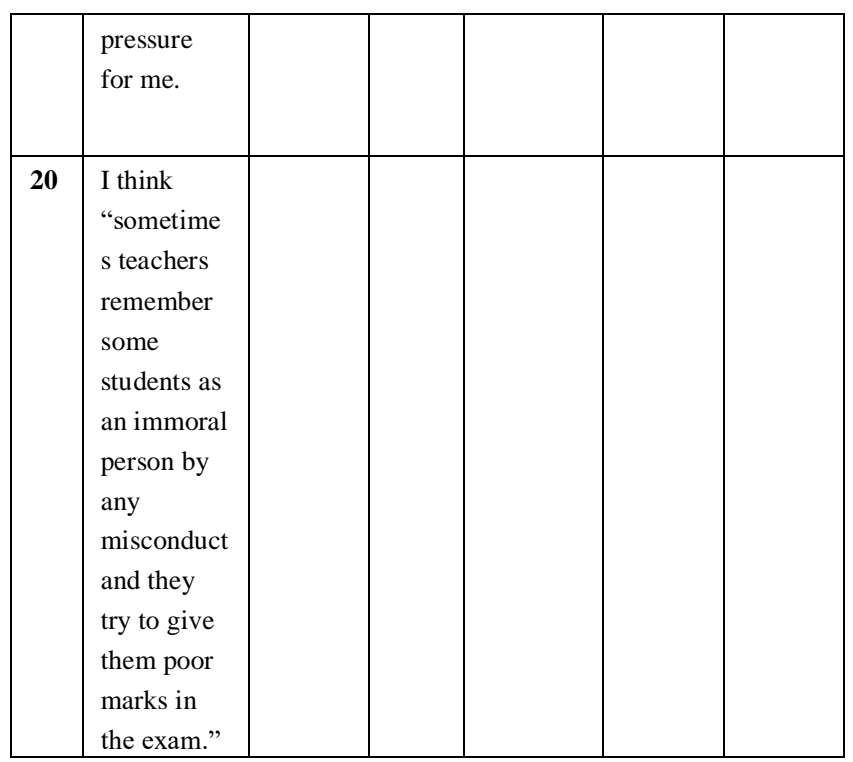

